\title{
Towards the Definitive VAT System - UPDATE ON THE IMPLEMENTATION of the VAT ACtion Plan
}

\begin{abstract}
The article provides an update on the implementation of the VAT Action Plan as regards the Commission's proposal setting out the fundamental principles of the definitive single EU VAT area and a number of short-term measures to improve the functioning of the VAT system until the definitive regime has been implemented. It explains problems with the current transitional VAT arrangements, goes through the options for review as set out in the Impact Assessment accompanying the proposal and develops reasoning behind the preferred option. It then presents the contents of the proposal: cornerstones of the definitive system and the "quick fixes" relating to the call-off stock arrangements, VAT identification number, chain transactions and the proof of the intra-Community transport of the goods. It includes the explanation of the notion of the certified taxable person introduced by the proposal.
\end{abstract}

Keywords: VAT, VAT Action Plan, SMEs, special scheme for small enterprises, VAT SME exemption

\section{The Commission's Proposal}

On 4 October 2017 the Commission adopted a proposal setting out the fundamental principles of a definitive single EU VAT area and a number of short-term measures to improve the functioning of the VAT system until the definitive regime has been implemented.

* The author works at the European Commission, Directorate-General for Taxation and Customs Union. The views expressed in this article are the author's alone and should not be attributed to the European Commission. 
The proposal covers amendments to the VAT Directive 2006/112/ EC, ${ }^{1}$ to the VAT Implementing Regulation ${ }^{2}$ and to the Regulation on Administrative Cooperation. ${ }^{3}$ In addition, it includes a follow-up Communication to the VAT Action Plan. ${ }^{4}$

The proposal stems from the VAT Action Plan, ${ }^{5}$ which designed a way forward to achieve a definitive VAT system for cross-border business-tobusiness (B2B) trade between Member States that would be based on the taxation of cross-border supplies of goods in the Member State of destination. In fact, as pointed out in the Explanatory Memorandum to the proposal for the Directive amending the VAT Directive 2006/112/EC, the first legislative step towards the definitive regime consists in two sub-steps: one including the cornerstones of the new system and another one providing detailed technical provisions for the implementation of the cornerstones, to be included in the Commission's proposal foreseen for adoption in $2018 .{ }^{6}$

\section{Problems with the Current System}

The VAT treatment of intra-EU supplies of goods has been subject, since 1 January 1993, to transitional arrangements, which entered into force as a result of the abolition of fiscal frontiers between Member States

${ }^{1}$ Proposal for a Council Directive amending Directive 2006/112/EC as regards harmonising and simplifying certain rules in the value added tax system and introducing the definitive system for the taxation of trade between Member States, Brussels, 4.10.2017, $\operatorname{COM}(2017) 569$ final.

${ }^{2}$ Proposal for a Council Implementing Regulation amending Implementing Regulation (EU) No. 282/2011 as regards certain exemptions for intra-Community transactions, Brussels, 4.10.2017, COM(2017) 568 final.

${ }^{3}$ Proposal for a Council Regulation amending Regulation (EU) No. 904/2010 as regards the certified taxable person, Brussels, 4.10.2017, COM(2017) 567 final.

${ }^{4}$ Communication from the Commission to the European Parliament, the Council and the European Economic and Social Committee on the follow-up to the Action Plan on VAT Towards a single EU VAT area - Time to act, Brussels, 4.10.2017, COM(2017) 566 final.

${ }^{5}$ Communication from the Commission to the European Parliament, the Council and the European Economic and Social Committee on an action plan on VAT - Towards a single EU VAT area - Time to decide, Brussles, 7.04.2016, COM(2016) 148 final.

${ }^{6}$ See, Proposal for a Council Directive amending Directive 2006/112/EC as regards harmonising and simplifying certain rules in the value added tax system and introducing the definitive system for the taxation of trade between Member States, referred to above, p. 4-5. 
by the end of $1992 .{ }^{7}$ According to these arrangements, the cross-border intra-EU movement of goods is split into two transactions: an intra-EU supply of goods exempt in the Member State of origin and an intra-EU acquisition of goods taxed in the Member State of destination. This means that, as regards intra-EU cross-border transactions in goods, the supplier does not charge VAT on his supply while the customer self-accounts for the VAT due via a mechanism that in practice amounts to a "reverse charge". These rules were intended to be temporary only, but are still in operation today, more than 20 years after their adoption.

A comprehensive retrospective evaluation of the EU VAT system ${ }^{8}$ conducted in 2011 identified two fundamental problems regarding the transitional arrangements. The first one is linked to the existing levels of VAT fraud and the second - to the complexity of the current transitional VAT system triggering additional costs for businesses engaging in intra-EU cross-border trade. ${ }^{9}$

The most recent, 2017 report on the VAT gap ${ }^{10}$ based on the VAT collection figures available for 2015, estimates the total amount of VAT lost across the EU-28 at EUR 151.5 billion. This represents a loss of $12 \%$ of the total expected VAT revenue. Although most of the fraud is considered to be domestic, the so-called Missing Trader Intra Community fraud (hereinafter MTIC fraud) contributes to the VAT gap. As pointed out in the Impact Assessment accompanying the proposal, ${ }^{11}$ this particular type of fraud exploits the endemic weakness of the current VAT system that allows goods to be bought cross-border with no VAT due to the break in the fractioned payment chain. The mechanism of the fraud is based on a cross-border purchase of goods by a fraudster followed by a domestic

7 Commission staff working document Impact Assessment accompanying the document proposal for a Council Directive amending Directive 2006/112/EC as regards harmonising and simplifying certain rules in the value added tax system and introducing the definitive system for the taxation of trade between Member States, Brussels, 4.10.2017, SWD(2017) 325 final, p. 16.

${ }^{8}$ A retrospective evaluation of elements of the EU VAT system, Final report TAXUD/2010/ DE/328, available at https:/ec.europa.eu/taxation_customs/sites/taxation/files/resources/documents/common/publications/studies/report_evaluation_vat.pdf [access: 5.01.2018].

${ }^{9}$ See Impact Assessment accompanying the proposal, quoted above, p. 20.

${ }^{10}$ Study and Reports on the VAT Gap in the EU-28 Member States: 2017 Final Report TAXUD/2015/CC/131, available at https://ec.europa.eu/taxation_customs/sites/taxation/ files/study_and_reports_on_the_vat_gap_2017.pdf [access: 5.01.2018].

${ }^{11}$ P. 24. 
supply by that fraudster. The fraudster doesn't pay the VAT on the crossborder purchase of goods, then charges and collects the VAT from his customer on the subsequent domestic supply and then goes missing with the VAT.

Another type of fraud that also exploits the rules of the transitional VAT system is the 'diversion fraud' that regards exportation of goods to third countries. This type of fraud can be established where a fraudster reports an intra-EU supply of goods but then diverts the goods to the domestic market as a result of which they remain in the same Member State and are sold without leaving its territory. ${ }^{12}$

The fraud can be committed in a number of different ways and has become more elaborated over the years. Its most damaging form known as a carousel fraud involves a series of transactions within and beyond the single market that create large unpaid VAT liabilities and fraudulent VAT repayment claims. ${ }^{13}$

The second problem with the transitional arrangements as put forward in the Impact Assessment is linked to the complexity of the system for intra-EU trade in goods which results in higher compliance costs for businesses trading cross-border as compared to businesses trading only domestically. A 2015 study Implementing the 'destination principle' to intra-EU B2B supplies of goods ${ }^{14}$ estimated that on average, the VAT cost of compliance per Euro of turnover is $11 \%$ higher for intra-EU trade compared with the corresponding VAT compliance per Euro of turnover for domestic trade.

The complexity of VAT system for intra-EU trade in goods stems from additional obligations meant to ensure control of trade in goods within the EU. These additional obligations are linked e.g. to the need for supplier to validate the status of his customer, to liability rules for non-established businesses, rules relating to consignment and call-off stocks, recapitulative statements etc. ${ }^{15}$

In addition, divergent application of the EU VAT rules across the Member States contributes to the complexity of VAT system for taxpayers involved in intra-EU trade. The main differences relate to the obligations

${ }^{12}$ See Impact Assessment accompanying the proposal, quoted above, p. 25.

${ }^{13}$ Ibidem.

${ }^{14}$ Final Report Contract: TAXUD/2013/DE/319, p. 194, available at https://ec.europa. eu/taxation_customs/sites/taxation/files/resources/documents/common/publications/ studies/ey_study_destination_principle.pdf [access: 5.01.2018].

15 See Impact Assessment accompanying the proposal, quoted above, Annex 5, Section 7, p. 125 and the following. 
and procedures set for businesses by different Member States and to the qualification of certain transactions and their VAT treatment. These differences stem from the numerous derogations and options in the VAT Directive, from the discretion left by the Directive to the Member States as regards its implementation and from varying interpretation of the Directive applied by the different Member States. ${ }^{16}$

\section{Options FOR REVIEW}

In order to address the above problems five options for review of the VAT rules on taxation of $\mathrm{B} 2 \mathrm{~B}$ transactions at destination were considered. In their definition two elements were essential: the place of taxation (and its link to the physical flow of the goods) and the person liable for payment of VAT.

Under Options 1, 2 and 3 the place of taxation would be the Member State of arrival of the goods (follow the flow of goods). Options 4 and 5 follow the contractual flow - the place of taxation under these options would be where the customer is established.

Under Options 2 and 5 the supplier would charge the VAT to his customer and the fractioned payments system would be kept. Options 1, 3 and 4 would be based on the reverse charge model with the customer self-assessing the VAT due and the collection of VAT suspended until the final consumption stage.

As regards technical dimension, Options 2, 4 and 5 would use the existing MOSS and would extend its use. Option 1 would rather build on the existing VIES system.

The options set out and then analysed in the Impact Assessment are shortly characterised below.

\section{Option 1}

Option 1 consisted in amending the rules for intra-EU B2B supplies of goods without, however, fundamental changes. The improvements would cover the issues identified by national tax administrations and stakeholders as the most burning ones and as to which the legal clarity and certainty would need to be enhanced. ${ }^{17}$ These were:

\footnotetext{
${ }^{16}$ See Impact Assessment accompanying the proposal, quoted above, p. 29.

17 The review process included, among others, public consultation, discussions within the Group on the Future of VAT and within the VAT Expert Group. See Impact Assessment accompanying the proposal, quoted above, p. 41.
} 
- the legal value of the VAT identification number of the customer as regards the exemption for the intra-EU supplies of goods in the Member State of departure of the goods;

- the VAT treatment of the call-off stock arrangements;

- the VAT treatment of the chain transactions;

- the rules on the proof of transport or dispatch of goods sold cross-border.

\section{Option 2}

Under this option taxation would follow the flow of goods. Where the goods are transported cross-border, VAT would be due in the Member State of arrival of goods at the end of the transport or dispatch. Where the goods are not transported or dispatched, the place of supply would be the Member State where the goods were located when the supply took place.

The person liable for collecting the VAT due would be by default the supplier of the goods. Where the supplier is not established for VAT purposes in the Member State of taxation, VAT on that particular supply would be accounted for using the One Stop Shop (hereinafter OSS) in the Member State of establishment. A single VAT registration in the Member State of establishment would be sufficient for the supplier to report and account for all the VAT due on his supplies carried out within the single market.

Certain cross-border supplies of goods would, however, continue, to be subject to the reverse charge. ${ }^{18}$

\section{Option 3}

Changes proposed under Option 3 were of a rather technical nature. The Option consisted in adapting the current rules while following the flow of the goods and applying the reverse charge for the collection of VAT. This option replaced the concept of two separate transactions of intra-EU supply and intra-EU acquisition by the concept of one single transaction - the intra-EU supply taxable in the Member State of destination.

Option 3 would not integrate OSS for the reporting and collection of the VAT due.

Option 3 would not change much as compared to the status quo - the place of taxation would continue to be the Member State of arrival of the goods and it would be the customer that would pay the VAT. It would

\footnotetext{
${ }^{18}$ Ibidem, p. 44.
} 
therefore neither address the problem of the MTIC fraud nor of other legislative issues caused by the current system such as treatment of the calloff stock, chain transactions etc. This option was therefore discarded.

\section{Option 4}

Under Option 4 the place-of-supply rules for goods would be aligned with those governing the place of supply of services and the reverse charge would be applied for the collection of VAT. The supply of goods would be the one taxable transaction.

The implementation of this Option would not require a fully extended OSS, but a limited OSS would be needed as regards goods supplied to a non-EU customer where those goods are located within the EU.

\section{Option 5}

Under Option 5 it was proposed to align the place-of-supply rules for goods with the contractual flow. The supplier would charge the VAT of his customer. This implies that the supplier would have to charge the VAT of the Member State of establishment of the customer which has contracted the supply, irrespective of whether the goods are transported cross-border. Suppliers not established in the Member State of taxation would report the VAT due with the use of OSS.

In order to assess the impacts of the policy options on the VAT fraud, administrative costs, the cash flow of the Member States and on the compliance costs and the cash flow of enterprises, the Commission ordered a study ${ }^{19}$ to be carried out by an independent consultant. This study covered also the macroeconomic impacts and the impacts from an internal market perspective and, in particular, the overall consistency in the VAT treatment of domestic and cross-border supplies of goods. ${ }^{20}$

4. Option Chosen

The option chosen on the basis of the impact assessment was Option 2 combined with Option 1.

Option 2 was estimated to best address the objectives of making the EU VAT system more robust and simpler and of providing a level playing

${ }^{19}$ See Implementing the 'destination principle' to intra-EU B2B supplies of goods, quoted above.

${ }^{20}$ See Impact Assessment accompanying the proposal, quoted above, section 6, p. 54. 
field for businesses while scoring well in terms of administrative costs for Member States.

As, however pointed out in the Impact Assessment, ${ }^{21}$ negotiation of a proposal based on Option 2 in Council and its implementation by the Member States would take several years. It was therefore considered reasonable to meet the request of Member States and businesses by incorporating in the proposal, as a short-term measure, certain improvements to the current system (the so-called quick fixes).

The choice was therefore made to combine Option 2 as the preferred option for implementing the VAT system, of which entry into force would be gradual, with Option 1 allowing in the short term certain limited improvements to the transitional VAT system currently in force.

As mentioned above (Section 1), in order to ease the transition into the definitive regime for both businesses and Member States it was decided to divide the first legislative step into two sub-steps. The first one will consist in setting the cornerstones of the definitive VAT system and will introduce them together with the short-term improvements to the current transitional system. The second sub-step will relate to the proposal covering the detailed implementing rules. It is currently scheduled for adoption by the Commission in 2018 with the entry into force in $2022 .^{22}$

As announced in the Communication on the follow-up to the Action Plan on VAT, ${ }^{23}$ in the second legislative step, the new VAT regime will be extended to cover all cross-border supplies - including supplies of services. The Commission would submit a proposal regarding this second step having carried out monitoring of the implementation of the first step. The VAT definitive regime could then be fully achieved.

${ }^{21}$ See p. 77.

${ }^{22}$ See Impact Assessment accompanying the proposal, quoted above, p. 79. When this article was written the proposal on the detailed technical measures for the operation of the definitive VAT system was in preparation. It was adopted by the Commission on 25.05.2018 - see Proposal for a Council Directive amending Directive 2006/112/EC as regards the introduction of the detailed technical measures for the operation of the definitive VAT system for the taxation of trade between Member States, Brussels, 25.05.2018, $\operatorname{COM}(2018) 329$ final.

${ }^{23}$ Quoted above, p. 7. 


\section{Cornerstones of the Definitive System}

The proposal ${ }^{24}$ introduces the cornerstones of the definitive VAT system for intra-Union trade. As mentioned above, another proposal will follow still this year that will develop detailed technical provisions for the actual implementation of these cornerstones. ${ }^{25}$ In addition, in order to ensure the effective functioning of the new system, changes regarding the administrative cooperation rules and important IT developments will be necessary.

The proposal amends current Article 402 of the Directive, which in the proposed wording stipulates that the VAT definitive system for intraEU trade will be based on the principle of taxation in the Member State of destination of the supply of goods or services. It is clarified that a new concept in relation to goods - the so-called "intra-Union supply" - will be introduced in the detailed technical provisions referred to above. This new single concept relating to taxable event will replace the current system of an exempt supply in the Member State of departure and a taxed "intraCommunity acquisition" in the Member State of destination. Under the new system, the 'place of supply' will be situated in the Member State of arrival of the goods.

The definitive regime will be based on the principle of liability for VAT of the supplier or the acquirer if he is a certified taxable person, in which case the latter will account for the VAT in his VAT return. Where the person liable for VAT is not established in the Member State in which the tax is due, he will be able to settle his declaration and payment obligations via a One-Stop Shop system. That system will also be used for the deduction of input VAT.

The Explanatory Memorandum to the proposal further clarifies that the definitive system could be based on the abolition of the recapitulative statement, the application of the overall invoicing rules of the Member State of the supplier, and the harmonisation of certain rules on invoicing, chargeable event and chargeability of VAT in relation to "intra-Union supplies" of goods. ${ }^{26}$

The proposal deletes current Articles 403 and 404 of the VAT Directive 2006/112/EC.

${ }^{24}$ See Proposal for a Council Directive amending Directive 2006/112/EC as regards harmonising and simplifying certain rules in the value added tax system and introducing the definitive system for the taxation of trade between Member States, referred to above.

${ }^{25}$ See above, footnote 23 .

${ }^{26}$ See p. $12,13$. 


\section{6. "Quick Fixes"}

\subsection{Certified taxable person}

The proposal for the Council Directive amending Directive 2006/112/ EC introduces the concept of the certified taxable person (new Article 13a). The concept is modelled on the concept of authorised economic operator in the field of customs. It allows declaration that a particular business can be considered to be a reliable taxpayer. The concept is important because certain simplification rules will apply in relation to transactions in which a certified taxable person is involved and it is one of the essential elements of the first step of the review regarding the definitive VAT system for intra-Union B2B trade.

The proposal sets out the cumulative criteria for qualifying as a certified taxable person.

They are established in the new Article 13a(2) as follows:

All the following criteria shall be required to be met in order to grant the status of a certified taxable person:

(a) the absence of any serious infringement or repeated infringements of taxation rules and customs legislation, as well as of any record of serious criminal offences relating to the economic activity of the applicant;

(b) the demonstration by the applicant of a high level of control of his operations and of the flow of goods, either by means of a system managing commercial and, where appropriate, transport records, which allows appropriate tax controls, or by means of a reliable or certified internal audit trail;

(c) evidence of financial solvency of the applicant, which shall be deemed to be proven either where the applicant has good financial standing, which enables him to fulfil his commitments, with due regard to the characteristics of the type of business activity concerned, or through the production of guarantees provided by insurance or other financial institutions or by other economically reliable third parties.

The proposal further establishes the cases of exclusion - where a taxable person cannot be granted the status of a certified taxable person (Article $13 \mathrm{a}(3))$, the Member State competent to grant and withdraw the certified taxable person status (Article 13a(4)), the right of taxable persons to appeal against decisions in this regard (Article 13a(5)) and the obligation of mutual recognition by the tax authorities of all the Member States (Article 13a(7)).

In addition, the proposal amending the VAT regulation on Administrative Cooperation ensures the inclusion of the certified taxable person status in the VIES system. It will provide the legal basis for an IT tool thanks to which Member States and operators will be able to check 
electronically whether an operator has the certified taxable person status. To that end it is necessary that all Member States store information on certified taxable person status electronically and that the competent authorities of each Member State ensure that confirmation of the certified taxable person status can be obtained by electronic means.

\subsection{Call-off stock}

Call-off stock arrangements relate to the situation in which a supplier transfers goods to a known acquirer without transferring the ownership of the goods but with a view that those goods should be supplied at a later stage. The acquirer has the right to take the goods from a stock of the supplier at his own discretion at which point a supply of goods takes place. In domestic situations such arrangements do not raise any specific problems, but where supplier and acquirer are situated in different Member States difficulties arise. ${ }^{27}$ Currently cross-border call-off stock arrangements give rise to:

- a deemed intra-EU supply by the supplier/transferor;

- a deemed intra-EU acquisition in the Member State of arrival of the goods made by the supplier/transferor;

- a domestic supply. ${ }^{28}$

The supplier/transferor of the goods is, as rule, obliged to be identified for VAT purposes in the Member State of arrival, which will allow him to declare the intra-Community acquisition.

The solution as regards the VAT treatment of the call-off stock arrangements put forward in the proposal (Articles 17a, 243(3) and 262) consists in qualifying them as a single supply in the Member State of departure and an intra-Community acquisition in the Member State where the stock is situated insofar as the transaction takes place between two certified taxable persons. This means that the supplier would not have to be identified for VAT purposes in every Member State in which he places goods under the call-off stock arrangements.

For the needs of fiscal control both the supplier and the acquirer would have to keep a register of call-off stock goods. In addition, the identity of the acquirer, to whom the goods will be supplied under call-off stock arrangements at a later stage, would have to be indicated in the recapitulative statement of the supplier.

${ }^{27}$ See Explanatory Memorandum to the proposal for a Council Directive amending Directive 2006/112/EC, referred to above, p. 10.

${ }^{28}$ See Impact Assessment accompanying the proposal, quoted above, p. 42. 
6.3. VAT identification number

The exemption for intra-Community supplies of goods as set out in Article 138(1) of the VAT Directive triggers the so-called carousel fraud - the problem that is intended to be solved by the new design of the definitive VAT system. However, as the national revenues across the EU are affected badly by this type of fraud, Member States requested interim solutions to deal with the problem.

The proposal addresses these requests in the new Article 138(1).

First of all, it stipulates as a substantive condition for the application of the exemption for intra-Community supplies of goods that the acquirer has to be identified for VAT purposes in a Member State other than that in which dispatch or transport of the goods begins. The supplier would have to verify the status of his customer via the VIES system before applying the exemption. This is already the case today, however, the consequences of the non-identification of the customer are different. On the basis of the proposal such a non-identification of the customer may lead to a rejection of the exemption. Today it may lead only to imposition of fines or administrative sanctions, but not to the refusal of the exemption itself. It is so because, according to the jurisprudence, under the current provisions of the VAT Directive the provision of the VAT identification number is not a substantive condition for the exemption from VAT of an intra-Community supply. ${ }^{29}$

Secondly, on the basis of the proposal, also the correct filing of a recapitulative statement (the so-called VIES listing) would become a substantive condition. This means that where the condition is not met, the administration would be able to refuse the exemption. The practical importance of the provision is significant as without correct information from the VIES system national tax authorities do not have the information regarding the arrival of untaxed goods into their territory.

${ }^{29}$ Judgments of 6 September 2012, Mecsek-Gabona, C-273/11, ECLI:EU:C:2012:547; of 27 September 2012, VSTR, C-587/10, ECLI:EU:C:2012:592; of 20 October 2016, Plöckl, C-24/15, ECLI:EU:C:2016:791 and of 9 February 2017, Euro-Tyre, C-21/16, ECLI:EU:C:2017:106. See Explanatory Memorandum to the proposal for a Council Directive amending Directive 2006/112/EC, referred to above, p. 10. 
6.4. Chain transactions

Chain transactions consist in successive supplies of the same goods by taxable persons giving rise to a single intra-Community transport of the goods. ${ }^{30}$ In such a situation, according to the jurisprudence, the transport should be ascribed to one supply within the chain in order to identify the transaction benefitting from the exemption for intra-Community supplies. ${ }^{31}$ In this context, Member States asked for amendments that would increase legal certainty as to determination of the supply within chain of transactions to which the intra-Community transport should be attributed. ${ }^{32}$

The proposal in Article 138a(1) stipulates that the intra-Community transport should be ascribed to the supply made by the provider to the intermediary operator, under the conditions that:

- the intermediary operator communicates the name of the Member State of arrival of the goods to the provider;

- the intermediary operator is identified for VAT purposes in a Member State other than that in which the dispatch or transport of the goods begins.

Where any of the above conditions is not met, in a chain transaction situation, the intra-Community transport should be ascribed to the supply made by the intermediary operator to the customer (Article 138a(2)).

These rules apply only where both the intermediary operator and the provider are certified taxable persons (Article 138a(3)).

6.5. Proof of the intra-community transport of the goods

Currently, the VAT Implementing Regulation ${ }^{33}$ does not cover the issue of evidence to be provided in order to prove that the conditions for the exemption of an intra-Community supply of goods are met. The Commission has been, however, faced with many requests on the side of the stakeholders to provide more legal certainty on this issue. The matter is

${ }^{30}$ See the Proposal Article 138a(3).

${ }^{31}$ Seejudgment of 6 April 2006, Emag Handel, C-245/04, para. 45;ECLI:EU:C:2006:232.

32 See Explanatory Memorandum to the proposal for a Council Directive amending Directive 2006/112/EC, referred to above, p. 11.

${ }^{33}$ Council Implementing Regulation (EU) No. 282/2011 of 15 March 2011 laying down implementing measures for Directive 2006/112/EC on the common system of value added tax, OJ L 77, 23.03.2011, p. 1. 
also of importance to tax administrations that must be able to monitor and ensure correct application of the exemption.

To address the problem the proposal introduces a rebuttable presumption in two specific cases which involve the certified taxable persons. Namely, Article 45a(1) stipulates that where:

- the vendor is a certified taxable person, he indicates that the goods have been transported or dispatched by him or by a third party on his behalf, and he is in possession of at least two items of non-contradictory evidence listed in the Regulation confirming the transport or dispatch;

- the person acquiring the goods is a certified taxable person and the vendor is in possession of the following:

$O$ a written statement from the person acquiring the goods that the goods have been transported or dispatched by him, or by a third party on his behalf, and referring to the Member State of destination of the goods;

o two items of non-contradictory evidence listed in the Regulation confirming the transport or dispatch;

it would be presumed that goods have been dispatched or transported to a destination outside their respective territory but within the Community.

A tax authority would be able to rebut the above presumption where there are indications of misuse or abuse by the vendor or the person acquiring the goods (Article 45a(2)).

As regards situations which are not covered by the above presumptions, for example because there are no certified taxable persons involved in them, the current rules apply.

\section{Closing Remarks}

The proposal constitutes a step on the way towards the definitive VAT system based on taxation at destination. It is difficult indeed to comment already at this stage on the way forward without knowing the more detailed rules to be presented later on this year. At the same time it is understandable that the Commission seeks the approval on the side of the Member States of the cornerstones of the future system before submitting detailed technical measures for its operation.

Given the time needed to reach an agreement in the Council and then to implement the definitive system, the introduction of "quick fixes" may be the way to reduce fraud and, overall, to improve the system. Some 
criticism of the solutions proposed can be found for example in the Opinion Statement of the Confédération Fiscale Européenne, ${ }^{34}$ which comments, among others, on the concept of the certified taxable person itself and the need for more clarity in relation to criteria for certification, it questions the application of certain quick fixes only to certified taxable persons and finds the rules on the proof of intra-Community supply too onerous.

The proposal is currently subject to discussions with the Member States in the Council.

At the time that this article was being completed the Commission adopted two further proposals implementing the VAT Action Plan ${ }^{35}$ and relating to the modernised rates policy ${ }^{36}$ and to the simplification package for small enterprises. ${ }^{37}$ Both proposals confirm the Commission's commitment to modernise the VAT system and adapt it to the developments in the single market and to the challenges posed by the fight against fraud.

\section{REFERENCES}

A retrospective evaluation of elements of the EU VAT system, Final report TAXUD/2010/ $\mathrm{DE} / 328$.

Commission staff working document Impact Assessment accompanying the document proposal for a Council Directive amending Directive 2006/112/EC as regards harmonising and simplifying certain rules in the value added tax system and introducing the definitive system for the taxation of trade between Member States, Brussels, 4.10.2017, SWD(2017) 325 final.

Communication from the Commission to the European Parliament, the Council and the European Economic and Social Committee on the follow-up to the Action Plan on VAT Towards a single EU VAT area - Time to act, Brussels, 4.10.2017, COM(2017) 566 final.

${ }^{34}$ Opinion Statement FC 9/2017 on European Commission Proposals on the way towards a single European VAT area, http://www.cfe-eutax.org/sites/default/files/04. CFE\%20Opinion\%20Statement\%20FC9_17\%20Proposals\%20towards\%20a\%20single\%20European\%20VAT\%20area_0.pdf [access: 19.01.2018].

35 The proposal on the detailed technical measures for the operation of the definitive VAT system was adopted by the Commission on 25.05.2018, see footnote 23 .

${ }^{36}$ Proposal for a Council Directive amending Directive 2006/112/EC as regards rates of value added tax, Brussels, 18.01.2018, COM(2018) 20 final.

${ }^{37}$ Proposal for a Council Directive amending Directive 2006/112/EC on the common system of value added tax as regards the special scheme for small enterprises, Brussels 18.01.2018, $\operatorname{COM(2018)~} 21$ final; See the Commission's press release IP/18/185 of 18.01.2018, http://europa.eu/rapid/press-release_IP-18-185_en.htm [access: 19.01.2018]. 
Communication from the Commission to the European Parliament, the Council and the European Economic and Social Committee on an action plan on VAT - Towards a single EU VAT area - Time to decide, Brussles, 7.04.2016, COM(2016) 148 final.

Proposal for a Council Directive amending Directive 2006/112/EC as regards harmonising and simplifying certain rules in the value added tax system and introducing the definitive system for the taxation of trade between Member States, Brussels, 4.10.2017, $\operatorname{COM}(2017) 569$ final.

Proposal for a Council Implementing Regulation amending Implementing Regulation (EU) No. 282/2011 as regards certain exemptions for intra-Community transactions, Brussels, 4.10.2017, COM(2017) 568 final.

Proposal for a Council Regulation amending Regulation (EU) No. 904/2010 as regards the certified taxable person, Brussels, 4.10.2017, $\operatorname{COM}(2017) 567$ final.

Streszczenie. Artykuł dotyczy postępów w realizacji planu działania w sprawie VAT w związku z propozycją Komisji dotyczącą podstawowych zasad, na których opierałby się jednolity unijny obszar VAT oraz pewnych krótkoterminowych środków mających na celu poprawę bieżącego funkcjonowania obecnego systemu VAT do czasu, aż docelowy system zostanie w pełni uzgodniony i wdrożony. Artykuł wyjaśnia problemy dotyczące funkcjonowania obecnego, tymczasowego systemu VAT, przedstawia przeanalizowane przez Komisję opcje co do kierunku reformy oraz rozwija uzasadnienie dotyczące preferowanej opcji. Artykuł następnie prezentuje najważniejsze punkty propozycji: podstawowe zasady ostatecznego systemu VAT oraz środki krótkoterminowe dotyczące tzw. call-off stock, numeru identyfikacji VAT, transakcji łańcuchowych oraz dowodu wewnątrzwspólnotowego transportu towarów. Przedstawia on również pojęcie podatnika certyfikowanego, dotyczące kategorii godnych zaufania przedsiębiorstw, wprowadzone w propozycji Komisji.

Słowa kluczowe: VAT, plan działania w sprawie VAT, małe przedsiębiorstwa, procedura szczególna dla małych przedsiębiorstw, zwolnienie z VAT małych przedsiębiorstw 